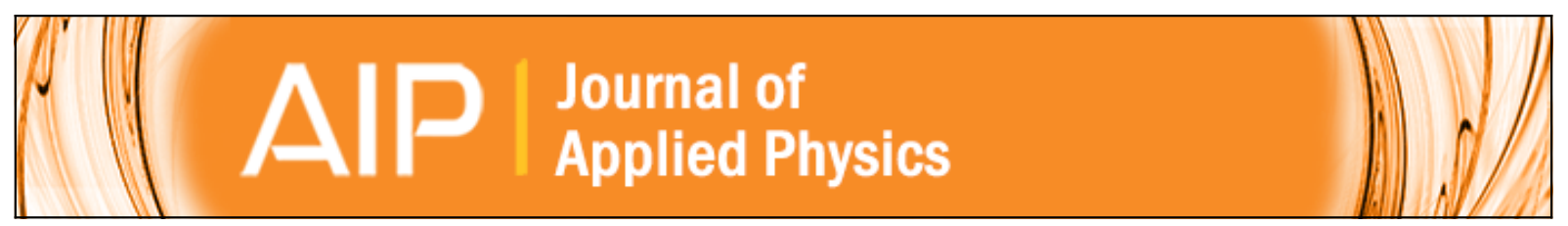

\title{
Amorphous silicon enhanced metal-insulator-semiconductor contacts for silicon solar cells
}

J. Bullock, A. Cuevas, D. Yan, B. Demaurex, A. Hessler-Wyser, and S. De Wolf

Citation: Journal of Applied Physics 116, 163706 (2014); doi: 10.1063/1.4900539

View online: http://dx.doi.org/10.1063/1.4900539

View Table of Contents: http://scitation.aip.org/content/aip/journal/jap/116/16?ver=pdfcov

Published by the AIP Publishing

\section{Articles you may be interested in}

Amorphous silicon passivated contacts for diffused junction silicon solar cells

J. Appl. Phys. 115, 163703 (2014); 10.1063/1.4872262

Compositional study of defects in microcrystalline silicon solar cells using spectral decomposition in the scanning transmission electron microscope

Appl. Phys. Lett. 102, 133902 (2013); 10.1063/1.4800569

Electron microscope verification of prebreakdown-inducing a-FeSi2 needles in multicrystalline silicon solar cells J. Appl. Phys. 113, 044505 (2013); 10.1063/1.4779601

Recycling of a defective metal insulator semiconductor solar cell by hot phosphoric acid J. Renewable Sustainable Energy 3, 013103 (2011); 10.1063/1.3549156

Aluminum/polyaniline/GaAs metal-insulator-semiconductor solar cell: Effect of tunneling on device performance Appl. Phys. Lett. 94, 223509 (2009); 10.1063/1.3149703

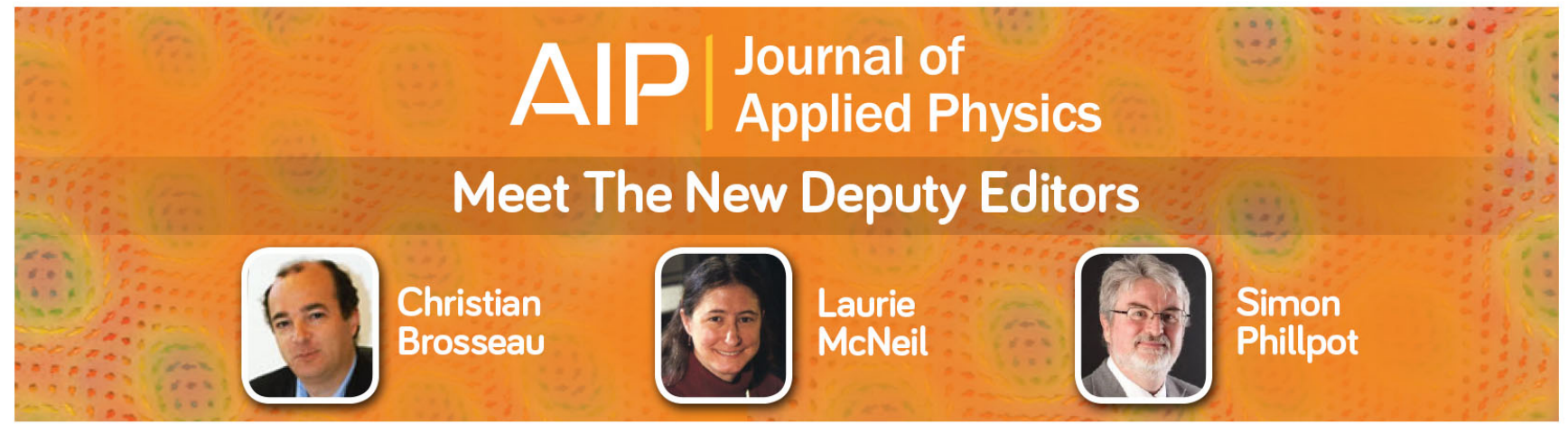




\title{
Amorphous silicon enhanced metal-insulator-semiconductor contacts for silicon solar cells
}

\author{
J. Bullock, ${ }^{1, a)}$ A. Cuevas, ${ }^{1}$ D. Yan, ${ }^{1}$ B. Demaurex,${ }^{2}$ A. Hessler-Wyser, ${ }^{2}$ and S. De Wolf ${ }^{2}$ \\ ${ }^{1}$ Research School of Engineering, The Australian National University, Canberra, ACT 0200, Australia \\ ${ }^{2}$ Ecole Polytechnique Fédérale de Lausanne (EPFL), Institute of Micro Engineering (IMT), Photovoltaics and \\ Thin Film Electronic Laboratory (PVLab), Maladière 71b, CH-200 Neuchâtel, Switzerland
}

(Received 2 September 2014; accepted 16 October 2014; published online 29 October 2014)

\begin{abstract}
Carrier recombination at the metal-semiconductor contacts has become a significant obstacle to the further advancement of high-efficiency diffused-junction silicon solar cells. This paper provides the proof-of-concept of a procedure to reduce contact recombination by means of enhanced metalinsulator-semiconductor (MIS) structures. Lightly diffused $\mathrm{n}^{+}$and $\mathrm{p}^{+}$surfaces are passivated with $\mathrm{SiO}_{2} / a-\mathrm{Si}: \mathrm{H}$ and $\mathrm{Al}_{2} \mathrm{O}_{3} / a-\mathrm{Si}: \mathrm{H}$ stacks, respectively, before the MIS contacts are formed by a thermally activated alloying process between the $a$-Si:H layer and an overlying aluminum film. Transmission/scanning transmission electron microscopy (TEM/STEM) and energy dispersive $\mathrm{X}$-ray spectroscopy are used to ascertain the nature of the alloy. Idealized solar cell simulations reveal that $\mathrm{MIS}\left(\mathrm{n}^{+}\right)$contacts, with $\mathrm{SiO}_{2}$ thicknesses of $\sim 1.55 \mathrm{~nm}$, achieve the best carrierselectivity producing a contact resistivity $\rho_{\mathrm{c}}$ of $\sim 3 \mathrm{~m} \Omega \mathrm{cm}^{2}$ and a recombination current density $J_{0 \mathrm{c}}$ of $\sim 40 \mathrm{fA} / \mathrm{cm}^{2}$. These characteristics are shown to be stable at temperatures up to $350{ }^{\circ} \mathrm{C}$. The $\operatorname{MIS}\left(\mathrm{p}^{+}\right)$contacts fail to achieve equivalent results both in terms of thermal stability and contact characteristics but may still offer advantages over directly metallized contacts in terms of manufacturing simplicity. (C) 2014 AIP Publishing LLC. [http://dx.doi.org/10.1063/1.4900539]
\end{abstract}

\section{INTRODUCTION}

High-efficiency solar cells require low carrier recombination at their surfaces to ensure high open-circuit and maximum power point voltages. In recent years, focused research into the electronic passivation of $c$-Si surfaces has resulted in the application of a wide range of high quality, industry applicable films for surface passivation, including $\mathrm{SiO}_{2}, \mathrm{SiN}_{\mathrm{x}}: \mathrm{H}, \mathrm{Al}_{2} \mathrm{O}_{3}, a-\mathrm{Si}: \mathrm{H}$, and stacks of these materials. As a consequence, the issue of surface recombination in the non-contacted surface regions of solar cells has diminished in importance, and recombination in the metallized regions has become one of major limiting factors of high efficiency homojunction solar cells.

In principle, the reduction of recombination at the contact interface can be achieved by the insertion of a thin dielectric interlayer between the silicon surface and the contacting metal, known as a metal-insulator-semiconductor (MIS) structure. The contact resistivity of MIS structures is strongly sensitive to both the thickness and the electronic properties of the dielectric, necessitating very precise control. ${ }^{1}$ A simplified theoretical figure-of-merit for comparing MIS contacts with different insulator types and thicknesses is given by ${ }^{2,3}$

$$
f=d \sqrt{m_{(e, h)}^{*} \Phi_{e f f(C, V)}},
$$

where $d$ represents the insulator thickness, and $m_{(e, h)}^{*}$ and $\Phi_{\text {eff(C,V) }}$ are the tunneling effective mass of the collected carrier (electron or hole) and the effective barrier height presented to that carrier. A small value of the parameter $f$ reflects a high tunneling probability, and hence a lower

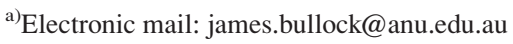

contact resistivity. Also to be considered is the resistance presented by the dielectric layer to the other carrier, which should preferably be maximized. Hence, an ideal dielectric film would present a low barrier and effective mass to one carrier and a large barrier and effective mass to the other. Unfortunately, no such material has been demonstrated to have this attribute whilst simultaneously providing significant surface passivation. Resultantly, $\mathrm{SiO}_{2}$ (Refs. 4-6) and $\mathrm{Al}_{2} \mathrm{O}_{3}$ (Refs. 7-9) have typically been used as the dielectric interlayers, as their thicker counterparts ( $>100 \AA)$ have been successfully implemented for surface passivation in the noncontacted regions. However, given the wide band-gap of these dielectrics and the resultant large barrier heights they present to electrons and holes in $c$-Si, tunnel-able layers are limited to a maximum thickness of $\sim 25 \AA$ in order to permit appreciable current flow. Achieving a high level of surface passivation with a $25 \AA$ thick dielectric (or thinner) remains a difficult task, compromising the benefit of implementing this type of MIS contact.

It has been shown that capping of thin dielectrics ( $\sim 10 \AA$ ) with silicon-based hydrogen-rich films can lead to dramatic improvements in surface passivation. ${ }^{10,11}$ The enhancement is often attributed to the diffusion of atomic hydrogen from the capping film to the $c$-Si/dielectric interface where it deactivates recombination centers. This suggests that plasma-enhanced-chemical-vapor-deposited (PECVD) hydrogenated amorphous silicon $(a-\mathrm{Si}: \mathrm{H})$, with its high hydrogen content $(10 \%-20 \%)^{12}$ could fulfill the requirements of a capping film.

A second interesting characteristic of $a-\mathrm{Si}: \mathrm{H}$ is its lowtemperature interaction with metals, specifically with aluminum. ${ }^{13}$ At annealing temperatures well below the Al-Si eutectic temperature $\left(577^{\circ} \mathrm{C}\right)$ silicon will dissolve into 
aluminum in low concentrations. ${ }^{14}$ The rate of dissolution is faster if the silicon is amorphous and faster still if the amorphous film has a high hydrogen concentration. ${ }^{15}$ Once dissolved, the silicon atoms can diffuse through the aluminum and crystalize out at nucleation points (defects, surfaces, grain boundaries, etc.), most likely with an aluminum doping concentration at the solubility limit. ${ }^{16,17}$

This paper provides a proof-of-concept of a simple procedure for achieving well-passivated MIS-type contacts using the above mentioned two characteristics of $a-\mathrm{Si}: \mathrm{H}$. The complete contact structure consists of a lightly doped phosphorus $\left(\mathrm{n}^{+}\right)$or boron $\left(\mathrm{p}^{+}\right)$surface, followed by a tunneling dielectric layer, which is capped with intrinsic $a-\mathrm{Si}: \mathrm{H}$. Thin $\mathrm{Al}_{2} \mathrm{O}_{3}$ and $\mathrm{SiO}_{2}$ layers are implemented as the tunneling dielectrics on $\mathrm{p}^{+}$and $\mathrm{n}^{+} c$-Si surfaces, respectively. These combinations are chosen in line with previous results of low surface recombination, assisted at least in part by the accumulation of majority carriers at the surface by the fixed charge density of the $\mathrm{Al}_{2} \mathrm{O}_{3}$ and $\mathrm{SiO}_{2}$ films. As the additional intrinsic $a-\mathrm{Si}: \mathrm{H}$ layer presents an impediment to current flow, following deposition is subsequently alloyed with an overlying aluminum film to create a high conductivity mixed-phase layer. The result is a contact structure that presents a contact resistivity $\rho_{\mathrm{c}}$ similar to that of conventional MIS contacts, together with a much lower recombination current $J_{0 \mathrm{c}}$, thanks to interface hydrogenation. Similar processes have previously been exploited for low temperature $p n$ junction formation ${ }^{17}$ and low resistance metal-silicon contacts (contact formation to $a-\mathrm{Si}: \mathrm{H}$ passivated wafers by means of annealing, "COSIMA"). ${ }^{18}$ It is also possible that the hydrogenation provided by the $a$-Si:H over layer could prove beneficial in the passivation of defects within the $c-\mathrm{Si}$, for example, boron oxygen defects ${ }^{19}$ and laser damaged regions. $^{20}$

A crucial parameter in the success of the above described $a$-Si:H enhanced MIS contact is the annealing temperature-one must be chosen at which aluminum interacts with the $a-\mathrm{Si}: \mathrm{H}$ but not with the underlying thin dielectric. For the $\mathrm{Al} / \mathrm{SiO}_{2}$ system, the maximum temperature of stability has been estimated to be in the range of $200-400{ }^{\circ} \mathrm{C},{ }^{21}$ whilst it is expected that the $\mathrm{Al} / \mathrm{Al}_{2} \mathrm{O}_{3}$ interaction will initiate at lower temperatures. ${ }^{1}$ Section III below presents an optimization of the annealing temperature, complemented with transmission/scanning transmission electron microscopy (TEM/STEM) and energy dispersive x-ray (EDX) spectroscopy analysis of changes to the layer composition. Once the fabrication process of the contact system is developed, the study proceeds to alter the thickness of the dielectric interlayer to find the best combination of contact characteristics.

The efficacy of the contact system, i.e., its selectivity towards electrons and holes, can be monitored by considering its resistive and carrier recombination properties. The contact resistivity $\rho_{\mathrm{c}}$ reflects the (undesired) resistance presented to the collected carrier (contact majority carrier), whereas the recombination current parameter of the contact $J_{0 c}$ provides information on the (desired) resistance or "blocking" action presented to the minority carrier. Whilst it is intuitive that simultaneous minimization of $\rho_{\mathrm{c}}$ and $J_{0 \mathrm{c}}$ leads to improvements in contact-selectivity, understanding the potential benefits of applying these contacts at the device level is not. Consideration must be made of the physical configuration, in which the contacts are to be applied. To address this point, Sec. IV includes device simulations to determine the optimum $\rho_{\mathrm{c}}-J_{0 \mathrm{c}}$ combination and corresponding contact configuration.

\section{FABRICATION AND CHARACTERIZATION OF THE CONTACT STRUCTURES}

To characterize the properties of the contacts, symmetrical test structures were prepared on float-zone, $>100 \Omega \mathrm{cm}$ resistivity, (100) oriented, p and n-type Si wafers. After saw damage etching and standard RCA cleaning, the wafers were diffused in quartz furnaces with boron (on n-type wafers) or phosphorus (on p-type wafers) so that in all cases the doping of the diffusion and substrate were opposed. A post diffusion alkaline etch was performed on the phosphorus diffusion to lower its surface concentration and increase the sheet resistance. Figure 1 provides the final dopant profiles of the boron $\left(\mathrm{p}^{+}\right)$and phosphorus $\left(\mathrm{n}^{+}\right)$diffusions as determined by electrochemical capacitance voltage measurements (WEP Wafer Profiler).

Following another RCA clean, $\mathrm{p}^{+}$samples were coated symmetrically at $200{ }^{\circ} \mathrm{C}$ with between 2 and 25 cycles of thermal atomic-layer-deposited (ALD) $\mathrm{Al}_{2} \mathrm{O}_{3}$ films (Beneq TFS 200). Alternating cycles of trimethylaluminium and water were used with pulse and purge durations chosen in line with a self-limiting reaction. The ALD growth rate, as measured from thicker films, was found to be $\sim 1 \AA$ /cycle; although for the ultra-thin films used in this study, the growth rate cannot be assumed to be perfectly linear. ${ }^{22}$

$\mathrm{SiO}_{2}$ films were grown into the $\mathrm{n}^{+}$samples in a clean quartz furnace at either $700{ }^{\circ} \mathrm{C}$ or $800{ }^{\circ} \mathrm{C}$ in pure oxygen (oxidation times typically less than $60 \mathrm{~s}$ ), resulting in film thicknesses between 1.3 and $2.0 \mathrm{~nm}$. Following the deposition/ growth of dielectrics, the samples were symmetrically capped with PECVD $a$-Si:H. Interestingly, different

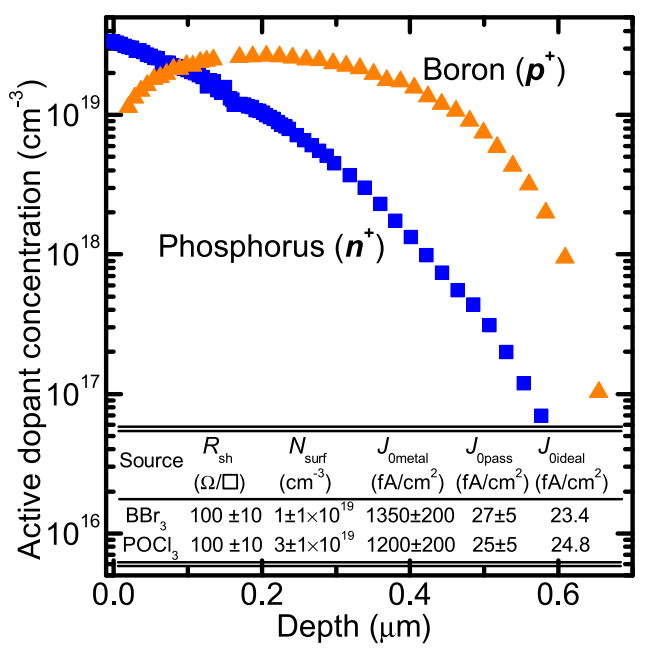

FIG. 1. Measured dopant profiles of $\mathrm{p}^{+}$and $\mathrm{n}^{+}$diffusions used in this study. The inset table provides details of the sheet resistance $\left(R_{\mathrm{sh}}\right)$ and surface dopant concentration $\left(N_{\text {surf }}\right)$ as well as reference recombination factors representative of the metallized $\left(J_{0 \text { metal }}\right)$, passivated $\left(J_{0 \text { pass }}\right)$, and simulated ideal $\left(J_{\text {Oideal }}\right)$ surfaces on the $\mathrm{n}^{+}$and $\mathrm{p}^{+}$diffusions. 
optimum capping $a$-Si:H films (deposited by different PECVD tools) were found for the $\mathrm{p}^{+}$and $\mathrm{n}^{+}$samples. The $\mathrm{p}^{+}$samples were coated with $\sim 30 \mathrm{~nm}$ of $a$-Si:H at a deposition temperature of $\sim 200^{\circ} \mathrm{C}$ (Oxford PlasmaLab 100) and subsequently annealed for $15 \mathrm{~min}$ at $400^{\circ} \mathrm{C}$ in forming gas ambient to activate the passivation. The $\mathrm{n}^{+}$samples were coated with $\sim 30 \mathrm{~nm}$ of $a$-Si:H at $\sim 300^{\circ} \mathrm{C}$ (Roth \& Rau AK400) and required no post-deposition anneal to activate the passivation. Aluminum was then evaporated symmetrically onto all samples to a thickness of $\sim 10 \mathrm{~nm}$ to mimic the metal contacts whilst allowing sufficient light through, in order to use the photoconductance decay (PCD) method to measure the effective minority carrier lifetime. PCD measurements were taken using a Sinton WCT120 instrument, and contact recombination factors $J_{0 \mathrm{c}}$ were extracted using the Kane and Swanson technique ${ }^{23}$ with an intrinsic carrier concentration $n_{\mathrm{i}}=8.6 \times 10^{9} \mathrm{~cm}^{-3}$ (at $297 \mathrm{~K}$ ).

Included in the inset of Figure 1 are reference values of the optimally passivated $J_{0 \text { pass }}$, directly metalized $J_{0 \text { metal }}$, and simulated ideal $J_{\text {oideal }}$ recombination factors of the $\mathrm{p}^{+}$and $\mathrm{n}^{+}$dopant profiles used in this study. The $J_{\text {Opass }}$ represents the lowest recombination factor that has been achieved experimentally for the $\mathrm{p}^{+}$and $\mathrm{n}^{+}$dopant diffusions, and is representative of non-contacted regions with state-of-the-art surface passivation. The $J_{0 \text { pass }}$ values were obtained in a separate study via PECVD $a$-Si:H $(\sim 30 \mathrm{~nm})$ for the $\mathrm{n}^{+}$surface and $\operatorname{ALD~} \mathrm{Al}_{2} \mathrm{O}_{3}(\sim 20 \mathrm{~nm})$ for the $\mathrm{p}^{+}$surface, in-line with previously reported low surface recombination results on these doped surfaces. ${ }^{13,24}$ The metallized recombination parameters $J_{0 \text { metal }}$ were measured on samples with $\sim 10 \mathrm{~nm}$ of aluminum evaporated directly onto the diffused surfaces. These values are representative of the recombination factor in the contacted regions if metallization is applied directly to the $c$-Si. The ideal recombination factors $J_{0 \text { ideal }}$ were simulated from the measured dopant profiles using Boltzmann statistics and the assumptions of no surface recombination (Auger recombination, ${ }^{25}$ mobility, ${ }^{26}$ and band gap narrowing ${ }^{27,28}$ models were utilized in this simulation). ${ }^{29}$ These values represent the theoretical minimum recombination factors that can be achieved with the dopant profiles in Figure 1. It is worth noting that the measured $J_{0 \text { pass }}$ recombination factors are, within measurement error, approximately equal to the simulated $J_{\text {0ideal }}$ values, indicating that surface recombination has been almost completely suppressed in the optimally passivated references.

Transfer-length-method (TLM) samples were fabricated on the same substrates, and using an identical procedure to the lifetime test samples up until the aluminum evaporation, which was instead deposited to a thickness of $\sim 1 \mu \mathrm{m}$ on only one side. The TLM contact pad patterns were photolithographically defined and isolated using an acidic metal etch. Pad spacings of $10-300 \mu \mathrm{m}$ were used in this study. Current-voltage measurements were performed at $\sim 297 \mathrm{~K}$ (Keithley 2425 Source Meter) and $\rho_{\mathrm{c}}$ was extracted as per the description given in Ref. 30.

STEM samples were prepared on single-side polished silicon wafers. Thermal $\mathrm{SiO}_{2} / a-\mathrm{Si}: \mathrm{H} / \mathrm{Al}$ contact structures were deposited on the polished surface, following which TEM lamellae were prepared by mechanical tripod polishing and ion milling. An FEI Tecnai Osiris instrument was used to take bright field (BF) and high angle annular dark field (HAADF) STEM micrographs and high sensitivity EDX maps of local aluminum, silicon, and oxygen concentrations. Contact structures with an $\mathrm{Al}_{2} \mathrm{O}_{3}$ tunnel layer were not analyzed by STEM and EDX micrographs due to ambiguity in the aluminum EDX signal.

Film thicknesses were monitored by fitting polarized reflectance data (J.A. Woolam M2000 ellipsometer) of single side polished silicon wafers deposited alongside lifetime and TLM samples. Given the dependence of $\mathrm{SiO}_{2}$ growth on dopant concentration, the $\mathrm{SiO}_{2}$ thickness samples were subjected to a phosphorus diffusion prior to oxidation to create an alike surface concentration.

Implicit in this study is the assumption that lifetime samples (with $\sim 10 \mathrm{~nm}$ of aluminum) and TLM samples $(\sim 1 \mu \mathrm{m}$ of aluminum) behave identically in terms of contact recombination. To explore the validity of this assumption, photoluminescence (PL) images were taken (BT Imaging LIS-R1) of a symmetrically passivated $c-\mathrm{Si}\left(\mathrm{n}^{+}\right) / \mathrm{SiO}_{2}(1.6 \mathrm{~nm}) / a-\mathrm{Si}: \mathrm{H}$ sample. On the rear side of this sample, half the area was covered with thick aluminum $(1 \mu \mathrm{m})$ and the other half with thin aluminum $(\sim 10 \mathrm{~nm})$. Figure 2 provides PL images of the sample taken with and without a $1000 \mathrm{~nm}$ short pass (SP) filter, after a $40 \mathrm{~min}, 250^{\circ} \mathrm{C}$ anneal step (see Sec. III A). Without the SP filter, greater rear-side reflection from the thick aluminum results in contrast between the two regions. With the filter, the effect of rear-side reflection is removed due to a penetration depth shallower than the thickness of the sample. An absence of contrast between the thick and thin aluminum regions in this image suggests that in both regions the carrier density profiles are very similar, and hence so are their respective surface recombination characteristics.

\section{OPTIMIZATION OF THE ALUMINUM-AMORPHOUS SILICON INTERMIXING}

\section{A. Temperature dependence of the characteristic contact parameters}

A significant component in the implementation of the proposed contact structure is the low-temperature interaction between $a-\mathrm{Si}: \mathrm{H}$ and aluminum. To investigate the lowest temperature at which the $\mathrm{Al} / a-\mathrm{Si}: \mathrm{H}$ interaction will commence, $\mathrm{Al} / a-\mathrm{Si}: \mathrm{H} / \mathrm{Al}_{2} \mathrm{O}_{3} / c-\mathrm{Si}\left(\mathrm{p}^{+}\right)$(referred to hereafter as

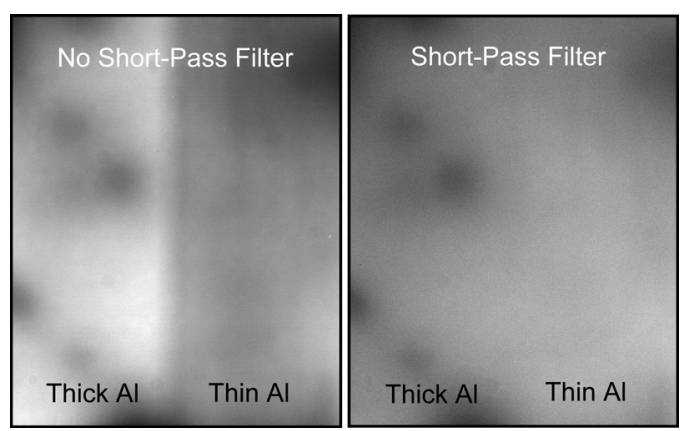

FIG. 2. PL images of an $\mathrm{Al} / a-\mathrm{Si}: \mathrm{H} / \mathrm{SiO}_{2}(\sim 1.6 \mathrm{~nm}) / c-\mathrm{Si}\left(\mathrm{n}^{+}\right)$sample taken with and without a $1000 \mathrm{~nm}$ short-pass filter. The two images are scaled individually to enhance contrast. 
$\operatorname{MIS}\left(\mathrm{p}^{+}\right)$) and $\mathrm{Al} / a-\mathrm{Si}: \mathrm{H} / \mathrm{SiO}_{2} / c-\mathrm{Si}\left(\mathrm{n}^{+}\right)$(referred to hereafter as MIS $\left.\left(\mathrm{n}^{+}\right)\right)$TLM structures were fabricated and annealed at different temperatures and $\rho_{\mathrm{c}}$ was monitored as a function of annealing time. Figure 3 shows the dependence of $\rho_{\mathrm{c}}$ on annealing time for the two contact structures, annealed at $200{ }^{\circ} \mathrm{C}$ and $250^{\circ} \mathrm{C}$. In this particular instance, the $\operatorname{MIS}\left(\mathrm{n}^{+}\right)$ and $\mathrm{MIS}\left(\mathrm{p}^{+}\right)$structures had insulator thicknesses of $\sim 1.6 \mathrm{~nm}$. It should be noted that the $\rho_{\mathrm{c}}$ values $\geq 1 \Omega \mathrm{cm}^{2}$ were extracted from current-voltage measurements that deviated from pure Ohmic behavior and, as such, they represent a lower-limit $\rho_{\mathrm{c}}$. As a reference, the directly metallized $\rho_{\mathrm{c}}$ values measured for the $\mathrm{n}^{+}$and $\mathrm{p}^{+}$surfaces are also provided in Figure 3. A slight reduction in $\rho_{\mathrm{c}}$ over the $40 \mathrm{~min}$ period is seen for the $200^{\circ} \mathrm{C}$ anneal, however, the reduction in $\rho_{\mathrm{c}}$ is prohibitively slow. Instead, annealing at $250^{\circ} \mathrm{C}$ provides an acceptable $\rho_{\mathrm{c}}$ for solar cell contacts after $20 \mathrm{~min}$, for both the $\operatorname{MIS}\left(\mathrm{p}^{+}\right)$and $\operatorname{MIS}\left(\mathrm{n}^{+}\right)$contacts. Additional annealing reduces $\rho_{\mathrm{c}}$ only slightly, after which $\rho_{\mathrm{c}}$ appears to saturate to a value of $\sim 10 \mathrm{~m} \Omega \mathrm{cm}^{2}$, which is still three orders of magnitude higher than for the directly metallized case. The saturation of $\rho_{\mathrm{c}}$ after $40 \mathrm{~min}$ of annealing suggests that the conductivity of the previously $a-\mathrm{Si}: \mathrm{H}$ is layer is no longer the limiting factor of conduction, and that now the tunneling interlayer dominates the measured resistivity. As demonstrated in Section IV A, the final saturated $\rho_{\mathrm{c}}$ values are strongly dependent on the dielectric thickness, suggesting that further optimization is possible.

As shown in Sec. IV A below, the $J_{0 \mathrm{c}}$ attainable with the $a$-Si:H enhanced MIS structures is significantly lower than that of basic MIS type contacts (without the $a$-Si:H capping) and that both structures show a strong $J_{0 \mathrm{c}}$ dependence on the dielectric layer thickness. In the case of a $\sim 1.6 \mathrm{~nm}$ film, as used in Figure 3, the $J_{0 \mathrm{c}}$ prior to the alloying step were $\sim 40$ and $90 \mathrm{fA} / \mathrm{cm}^{2}$ for the $a$-Si:H enhanced MIS $\left(\mathrm{n}^{+}\right)$and $\operatorname{MIS}\left(\mathrm{p}^{+}\right)$, respectively. Over the $40-\mathrm{min}, 250^{\circ} \mathrm{C}$ alloying anneal the $J_{0 \mathrm{c}}$ of the MIS $\left(\mathrm{n}^{+}\right)$contact did not change significantly, remaining within the margins of measurement uncertainty. The $J_{0 \mathrm{c}}$ of the $\operatorname{MIS}\left(\mathrm{p}^{+}\right)$contact increased by approximately a factor of two under these conditions, from 90 to $\sim 160 \mathrm{fA} / \mathrm{cm}^{2}$.

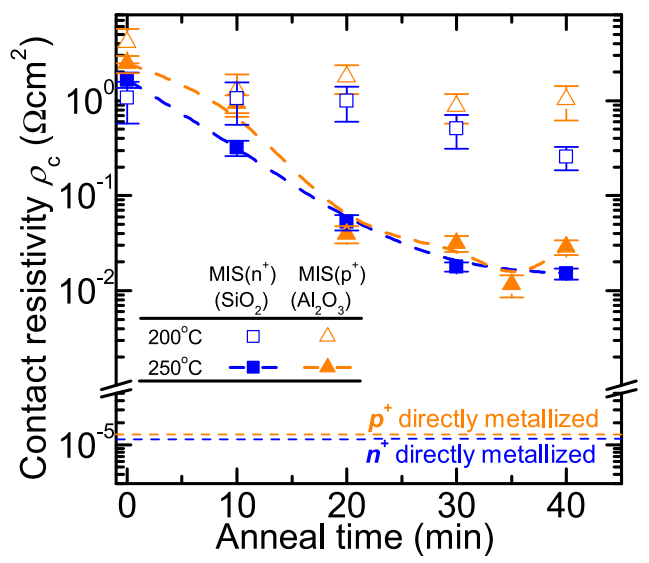

FIG. 3. Anneal time dependent $\rho_{\mathrm{c}}$ for $\mathrm{MIS}\left(\mathrm{p}^{+}\right)$and $\mathrm{MIS}\left(\mathrm{n}^{+}\right)$contacts with $\sim 1.6 \mathrm{~nm}$ dielectric layers. Lines provide a guide to the eyes only and error bars are based on the estimated measurement error. Dotted horizontal lines represent directly metallized $\rho_{\mathrm{c}}$ values for the $\mathrm{n}^{+}$and $\mathrm{p}^{+}$diffusions.
The annealing conditions described above reflect the lowest temperature at which the $a$-Si:H/Al interaction, and hence contact formation, will occur. Some conventional solar cell processing steps, such as the application of PECVD $a$ - $\mathrm{SiN}_{\mathrm{x}}: \mathrm{H}$ passivation and antireflection coating, require temperatures of up to $400{ }^{\circ} \mathrm{C}$. Hence, it is of interest from a processing perspective to know the stability of $J_{0 \mathrm{c}}$ at those temperatures as well. Provided in Figure 4 are the $J_{0 c}$ values for the $\operatorname{MIS}\left(\mathrm{p}^{+}\right)$and $\operatorname{MIS}\left(\mathrm{n}^{+}\right)$contacts as a function of anneal time for annealing temperatures between $300^{\circ} \mathrm{C}$ and $400^{\circ} \mathrm{C}$. All samples received a $40 \mathrm{~min}, 250^{\circ} \mathrm{C}$ anneal prior to the commencement of the higher temperature annealing. The $J_{0 \mathrm{c}}$ of the $\mathrm{MIS}\left(\mathrm{n}^{+}\right)$exhibits no significant increase after $45 \mathrm{~min}$ at $350^{\circ} \mathrm{C}$; however, at $400^{\circ} \mathrm{C}$ the $J_{0 \mathrm{c}}$ underwent a 10 fold increase over the same time period. This is in alignment with temperatures reported in the literature for the initiation of the $\mathrm{SiO}_{2} / \mathrm{Al}$ interaction, ${ }^{21}$ suggesting that aluminum may be moving through the oxide layer.

The MIS $\left(\mathrm{p}^{+}\right)$exhibited a poorer stability at $350^{\circ} \mathrm{C}$, increasing to over $\sim 1000 \mathrm{fA} / \mathrm{cm}^{2}$ - close to the directly metallized $J_{\text {Ometal }}$ value of $\sim 1350 \mathrm{fA} / \mathrm{cm}^{2}$ given in Fig. 1 . Nevertheless, a reasonable stability was observed for the $\operatorname{MIS}\left(\mathrm{p}^{+}\right)$at $300^{\circ} \mathrm{C}$, with a final $J_{0 \mathrm{c}}$ of $\sim 500 \mathrm{fA} / \mathrm{cm}^{2}$ after $45 \mathrm{~min}$ of annealing, a value well below the directly metallized case.

Contact resistance measurements taken after higher temperature annealing revealed small reductions in $\rho_{\mathrm{c}}$ but remained orders of magnitude above the directly metalized case-again supporting the conclusion that $\rho_{\mathrm{c}}$ is now dominated by tunneling through the dielectric layer.

\section{B. Temperature dependent compositional analysis}

To investigate the compositional changes responsible for the above discussed thermal dependence of the contact characteristics, STEM analysis and accompanying EDX mapping of local $\mathrm{Al}, \mathrm{Si}$, and $\mathrm{O}$ concentrations were performed on $\operatorname{MIS}\left(\mathrm{n}^{+}\right)$contacts. As a baseline from which to compare annealed samples, an $\mathrm{Al} / a-\mathrm{Si}: \mathrm{H}(\sim 30 \mathrm{~nm}) / \mathrm{SiO}_{2}$ $(\sim 2 \mathrm{~nm}) / c$-Si contact structure was imaged before the alloying anneal. Figure 5(a) provides a HAADF STEM image and

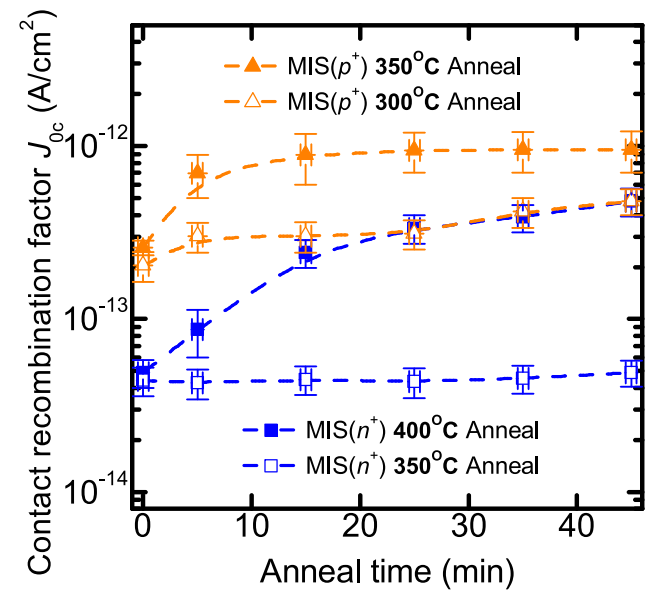

FIG. 4. Temperature stability of $\operatorname{MIS}\left(\mathrm{p}^{+}\right)$and $\operatorname{MIS}\left(\mathrm{n}^{+}\right)$as assessed by changes in $J_{0 \mathrm{c}}$. Lines provide a guide to the eyes only, error bars are based on the estimated measurement error. 

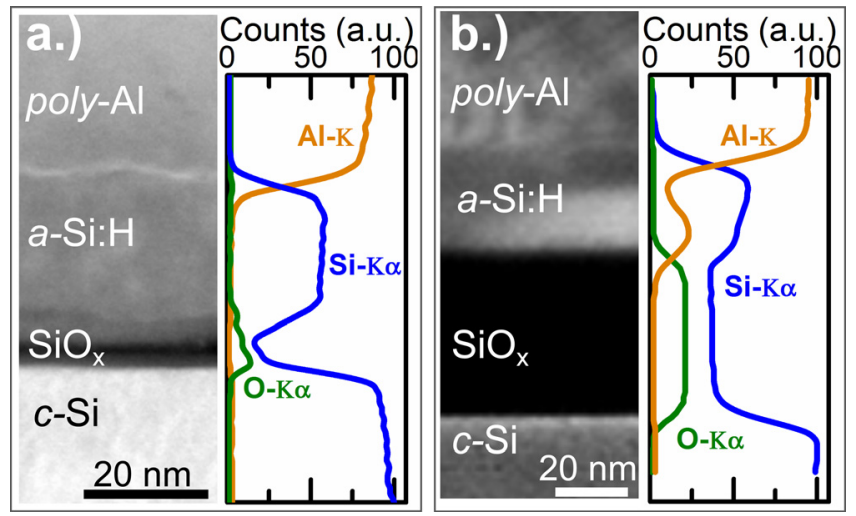

FIG. 5. HAADF STEM and EDX line scans of local Al, O, and Si distribution for (a) an $\mathrm{Al} / a-\mathrm{Si}: \mathrm{H}(\sim 30 \mathrm{~nm}) / \mathrm{SiO}_{2}(\sim 2 \mathrm{~nm}) / c$-Si contact in its asdeposited state and (b) an $\mathrm{Al} / a-\mathrm{Si}: \mathrm{H}(\sim 30 \mathrm{~nm}) / \mathrm{SiO}_{2}(\sim 50 \mathrm{~nm}) / c$-Si contact after $40 \mathrm{~min}$ alloying at $250{ }^{\circ} \mathrm{C}$. The line-scans account for the differences in both composition and density of the different films.

corresponding EDX line-scans of the local Al, Si, and O distribution of the un-annealed contact. Evident in the HAADF STEM image are the $\mathrm{SiO}_{2}, a-\mathrm{Si}: \mathrm{H}$ and $\mathrm{Al}$ layers on $c$-Si, with an additional unintentional interlayer between the $a$ $\mathrm{Si}: \mathrm{H}$ and $\mathrm{SiO}_{2}$ layers. No evidence of significant interaction between the $\mathrm{Al}$ and $a$-Si:H layers is seen in the STEM image, as supported by the EDX line scans which show a sharp decline in $\mathrm{Al}$ accompanied by a sharp increase in $\mathrm{Si}$ concentration at the $\mathrm{Al} / a-\mathrm{Si}: \mathrm{H}$ interface. These line scans also suggest that the intermediate layer between the $\mathrm{SiO}_{2}$ and $a-\mathrm{Si}: \mathrm{H}$ layers is a sub-stoichiometric oxide species $\left(\mathrm{SiO}_{\mathrm{x}<2}\right)$. Additional high-resolution (HR) TEM micrographs (not shown here) of the $a-\mathrm{Si}: \mathrm{H}$ layer revealed no sign of crystallization.

To inspect the compositional changes at $250^{\circ} \mathrm{C}, \mathrm{STEM}$ imaging and EDX mapping and line scans of an $\mathrm{Al} / a-\mathrm{Si}: \mathrm{H}$ $(\sim 30 \mathrm{~nm}) / \mathrm{SiO}_{2}(\sim 50 \mathrm{~nm}) / c-\mathrm{Si}$ structure after a $40 \mathrm{~min}$ at $250{ }^{\circ} \mathrm{C}$ anneal were undertaken. A thicker $\mathrm{SiO}_{2}$ layer was used in this instance to obtain a clearer distinction between interfaces. Figure 6(a) shows the HAADF STEM image and corresponding $\mathrm{Al}, \mathrm{Si}$, and $\mathrm{O}$ EDX mappings of the annealed contact structure. In contrast to the un-annealed sample, the Al mapping in Figure 6(a) shows a local protrusion of $\mathrm{Al}$ through the previously deposited $a$-Si:H layer, with an $\mathrm{Al}$ accumulation at the $\mathrm{SiO}_{2}$ surface. This is supported by a corresponding low $\mathrm{Si}$ concentration in the same region as seen in the $\mathrm{Si}$ EDX mapping. It appears that the $\mathrm{SiO}_{2}$ layer limits any significant movement of $\mathrm{Al}$ further towards the $c$-Si at this annealing temperature. The EDX line scans included in Figure 5(b) illustrate the compositional variation through one of these local $\mathrm{Al}$ rich regions and show accumulation of $\mathrm{Al}$ at the $\mathrm{SiO}_{2}$ surface. Localized atomic composition analysis reveals a small silicon concentration $(\sim 1$ at. \%) in the $\mathrm{Al}$ layer, indicating partial dissolution of $\mathrm{Si}$ into $\mathrm{Al}$. More significantly, Al concentrations of up to 40 at. \% are detected in the underlying $a-\mathrm{Si}: \mathrm{H}$ film. These concentrations, which are well above the doping solubility limit, suggest that the previously $a$-Si:H layer is now semi-metallic and hence highly conductive. The saturation in $\rho_{\mathrm{c}}$ seen in Figure 3 is therefore likely dominated by carrier tunneling through the still intact thin dielectric layer. The region of high $\mathrm{Al}$ concentration within the $a$-Si:H layer is seen to be correlated with a region of contrast in the HAADF STEM image. HR TEM micrographs of the same region reveals lattice fringes indicative of the presence of crystallites, as shown in Figure 7.

Additional thermal treatment for $15 \mathrm{~min}$ at $400{ }^{\circ} \mathrm{C}$ results in aluminum completely replacing the previously $a$-Si:H layer, with a compositional concentration close to $100 \%$, as seen in Figure 6(b), which shows the EDX mapping after this anneal step. Also evident in this figure is that the $\mathrm{SiO}_{2}$ layer is acting as a barrier to further $\mathrm{Al}$ diffusion. The preservation of the $\mathrm{SiO}_{2}$ layer is consistent with the results for $\operatorname{MIS}\left(\mathrm{n}^{+}\right)$in Figure 4, which indicate that after 15 min at $400{ }^{\circ} \mathrm{C}$ the $J_{0 \mathrm{c}}$ is $\sim 250 \mathrm{fA} / \mathrm{cm}^{2}$, still much lower than the corresponding value for the directly metallized surface. A HR TEM image, shown in Figure 7, reveals extensive crystallization (of aluminum-rich regions) in the previously $a$-Si:H layer.

\section{THE TRADE-OFF BETWEEN RECOMBINATION CURRENT AND CONTACT RESISTANCE}

\section{A. Dependence of contact characteristics on insulator thickness}

Using the $40-\min , 250^{\circ} \mathrm{C}$ anneal identified in Sec. III A as optimal, the contact characteristics of $\operatorname{MIS}\left(\mathrm{n}^{+}\right)$and $\operatorname{MIS}\left(\mathrm{p}^{+}\right)$structures with differing insulator thicknesses were
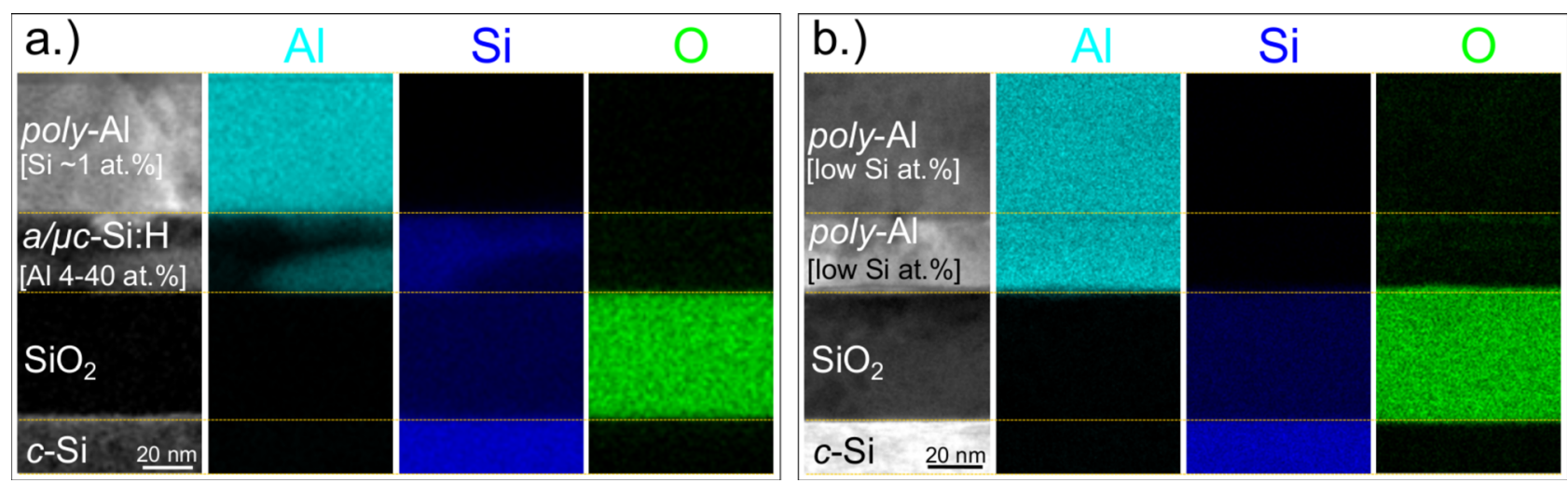

FIG. 6. HAADF STEM and EDX mappings of the local Al, O, and Si concentrations for an $\mathrm{Al} / a-\mathrm{Si}: \mathrm{H}(\sim 30 \mathrm{~nm}) / \mathrm{SiO} 2(\sim 50 \mathrm{~nm}) / c-\mathrm{Si}$ contact $(\mathrm{a})$ after $40 \mathrm{~min}$ annealing at $250^{\circ} \mathrm{C}$ and (b) after an additional 15 min annealing at $400^{\circ} \mathrm{C}$. 


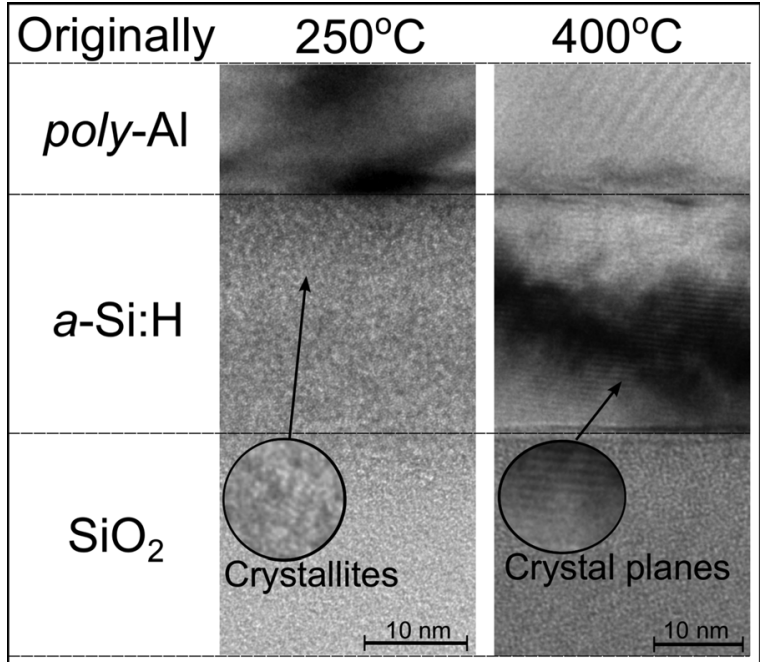

FIG. 7. HR TEM micrographs showing signs of crystallization in the $a-\mathrm{Si}: \mathrm{H}$ layer for $\mathrm{Al} / a-\mathrm{Si}: \mathrm{H} \quad(\sim 30 \mathrm{~nm}) / \mathrm{SiO}_{2} \quad(\sim 50 \mathrm{~nm}) / c-\mathrm{Si}$ contact structures annealed at $250^{\circ} \mathrm{C}$ for $40 \mathrm{~min}$ (left) and at $250^{\circ} \mathrm{C}$ for $40 \mathrm{~min}$ with an additional 15 min at $400^{\circ} \mathrm{C}$ (right).

measured. As a baseline from which to compare these results, a set of reference MIS samples were also prepared on identical dopant diffusions, without the $a$-Si:H capping step (referred to hereafter as basic MIS). Figures 8(a) and 8(b) provide the $\rho_{\mathrm{c}}$ and $J_{0 \mathrm{c}}$ dependence on $\mathrm{SiO}_{2}$ thickness, for the $a$-Si:H capped $\mathrm{MIS}\left(\mathrm{n}^{+}\right)$contact, alongside the corresponding basic $\operatorname{MIS}\left(\mathrm{n}^{+}\right)$reference samples. Also included in these plots are horizontal dotted lines corresponding to the directly metallized $\rho_{\mathrm{c}}$ and $J_{0 \text { metal }}$ and the optimally passivated $J_{\text {Opass. }}$. In agreement with the theoretical probability for quantummechanical tunneling, a strong increase in $\rho_{\mathrm{c}}$ is observed as a result of increasing dielectric thickness-spanning more than three orders of magnitude for a $5 \AA$ difference in $\mathrm{SiO}_{2}$ thickness. Over the range measured, it can be seen that there is no significant difference in the thickness dependence of $\rho_{\mathrm{c}}$ between the $a$-Si:H capped and basic MIS structures. This further supports the conclusion that following the alloying step, the passage of current through the $a$-Si:H capped $\operatorname{MIS}\left(\mathrm{n}^{+}\right)$is, like the basic $\operatorname{MIS}\left(\mathrm{n}^{+}\right)$structure, limited only by carrier tunneling through the dielectric layer.

Coupled with the increasing $\rho_{\mathrm{c}}$ as a function of dielectric thickness is a decreasing $J_{0 \mathrm{c}}$. The $a$-Si:H capped and basic MIS( $\left.\mathrm{n}^{+}\right)$structures both offer a significant reduction in recombination, as compared to the directly metallized case. In addition, it can be seen that for both structures, converse to the $\rho_{\mathrm{c}}$ trend, $J_{0 \mathrm{c}}$ decreases with increasing insulator thickness. Most significantly, it can be seen that the $J_{0 c}$ of the $a$-Si:H capped $\mathrm{MIS}\left(\mathrm{n}^{+}\right)$is consistently almost an order of magnitude lower than the basic MIS $\left(\mathrm{n}^{+}\right)$. A dielectric thickness of $1.7 \mathrm{~nm}$ is sufficient to achieve the lower limit (optimally passivated) recombination factor of $\sim 25 \mathrm{fA} / \mathrm{cm}^{2}$, but at the expense of a high $\rho_{\mathrm{c}}$. This value is approximately identical to that corresponding to Auger recombination within the $\mathrm{n}^{+}$region, which suggests that even lower recombination factors may be attainable by reducing the dopant dose of the underlying diffusion. The 700 and $800^{\circ} \mathrm{C}$ oxides exhibit similar $\rho_{\mathrm{c}}$ and $J_{0 \mathrm{c}}$ trends; a slightly earlier transition to lower $J_{0 \mathrm{c}}$ and higher $\rho_{\mathrm{c}}$ for the higher temperature oxide may reflect differences in the density of the two $\mathrm{SiO}_{2}$ films.

An analogous set of results for the MIS $\left(\mathrm{p}^{+}\right)$contact characteristics as a function of the number of ALD $\mathrm{Al}_{2} \mathrm{O}_{3}$ cycles is provided in Figures 8(c) and 8(d). Similar to the trend seen for the $\mathrm{MIS}\left(\mathrm{n}^{+}\right)$structures, both the $a$-Si:H capped and basic MIS $\left(\mathrm{p}^{+}\right)$structures exhibit alike contact resistance dependences on thickness. Structures which were fabricated with more than 15 ALD cycles $(\sim 1.5 \mathrm{~nm})$ were measured to produce large $\rho_{\mathrm{c}}$ values and general nonlinear current-voltage behavior. The rapid onset of high resistance contact behavior seen for both $\operatorname{MIS}\left(\mathrm{p}^{+}\right)$structures is attributable to the large valence band offset between the $c$-Si and $\mathrm{Al}_{2} \mathrm{O}_{3}$ (Ref. 31) and the corresponding high value of $f$ (Eq. (1)).

In terms of recombination, again both the $a$-Si:H capped and basic $\operatorname{MIS}\left(\mathrm{p}^{+}\right)$structures produce lower recombination factors than the directly metallized case, with the $a-\mathrm{Si}: \mathrm{H}$ capped structures producing the lowest recombination

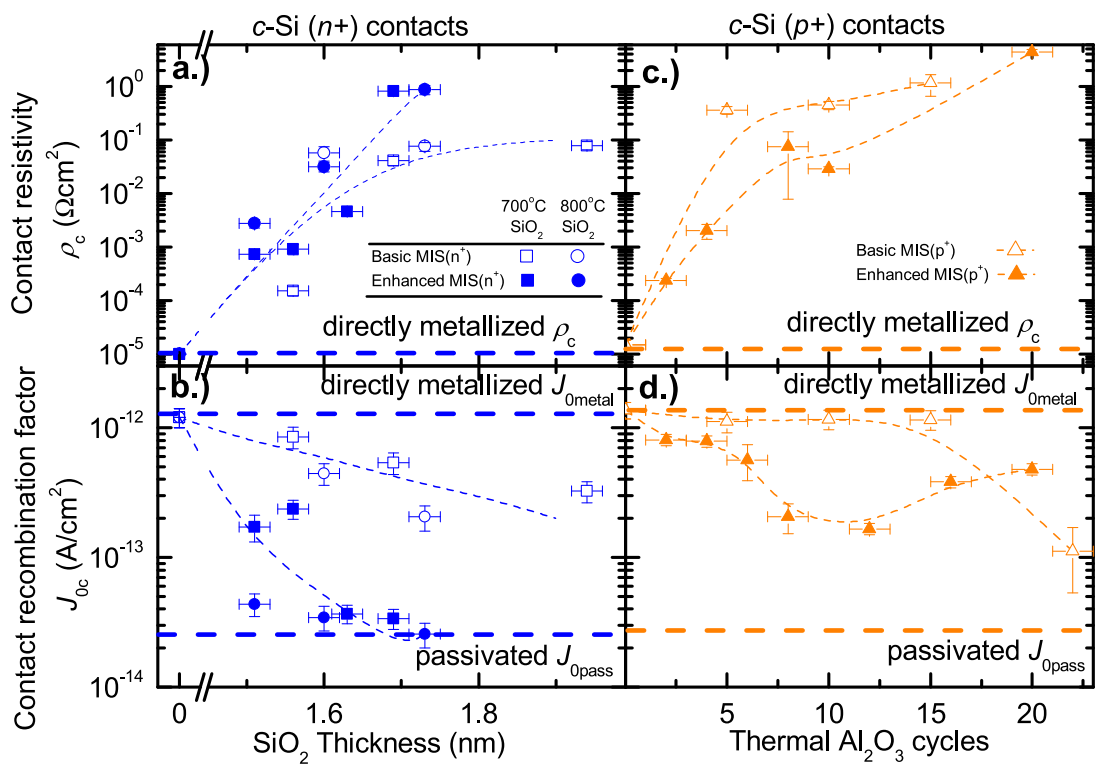

FIG. 8. Contact resistivity $\rho_{\mathrm{c}}$ of (a) $\operatorname{MIS}\left(\mathrm{n}^{+}\right)$and (c) $\operatorname{MIS}\left(\mathrm{p}^{+}\right)$structures and contact recombination factor $J_{0 \mathrm{c}}$ for (b) MIS $\left(\mathrm{n}^{+}\right)$and (d) MIS $\left(\mathrm{p}^{+}\right)$structures as a function of insulator thickness. Lines provide a guide to the eyes only, error bars are based on the estimated error in measurement. The adjacent plot includes some data which have previously been presented elsewhere. ${ }^{35}$ 


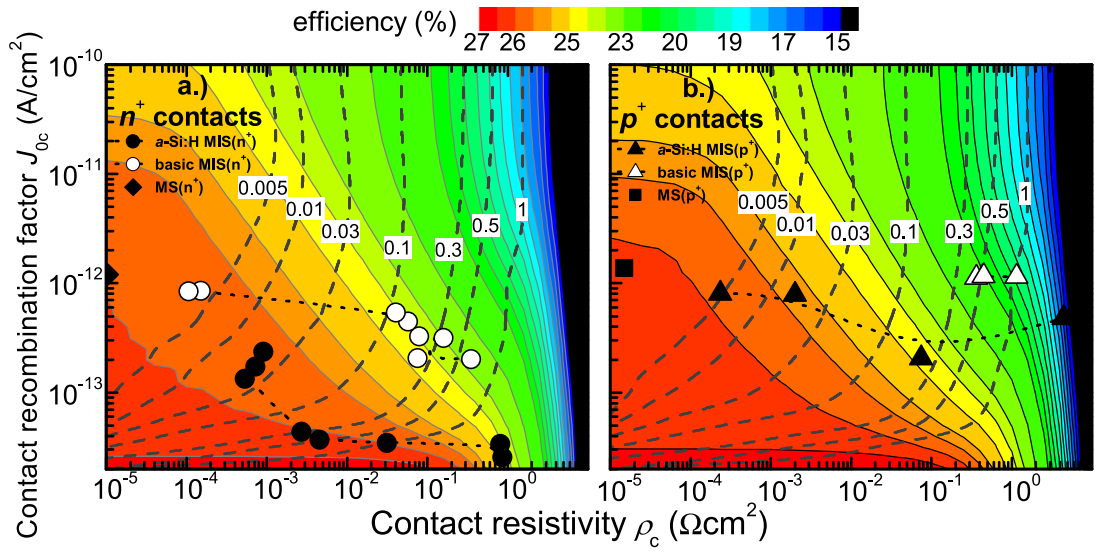

FIG. 9. Simulated optimum contact fraction $m_{\mathrm{f}}$ (dashed lines) and resultant idealized efficiency (contour plot) as a function of rear contact $\rho_{\mathrm{c}}$ and $J_{0 \mathrm{c}}$ for (a) $\mathrm{n}^{+}$contacts and (b) $\mathrm{p}^{+}$contacts presented in this paper. All values to the right of the $100 \%$ contact fraction lines were simulated with full area contacts. Directly metalized, basic MIS, and $a$ Si:H capped MIS data points are superimposed on top of the contours to reflect their relative carrier-selectivity. The varied parameter in the MIS contact data trends is the insulator layer thicknesses.

factors within the dielectric thickness range of relevance. However, the level of passivation is consistently less than that provided by the $\operatorname{MIS}\left(\mathrm{n}^{+}\right)$structures-reaching at best $\sim 150 \mathrm{fA} / \mathrm{cm}^{2}$ - which is significantly higher than the optimally passivated case, but still approximately an order of magnitude lower than the directly metallized $\mathrm{p}^{+}$surface. The passivation quality of the $a$-Si:H enhanced $\mathrm{MIS}\left(\mathrm{p}^{+}\right)$appears to stop improving after ten cycles of $\mathrm{Al}_{2} \mathrm{O}_{3}$-producing a local minimum.

The lower level of surface passivation could be associated with a minority/majority capture cross-section ratio $\sigma_{\mathrm{n}} / \sigma_{\mathrm{p}}$ greater than unity, which is expected for the recombination active defects present at the $\mathrm{Al}_{2} \mathrm{O}_{3} / c$-Si interface. ${ }^{32}$ In addition, the relatively low work function of aluminum may induce downwards band bending increasing the minority carrier concentration at the $c$-Si surface. A metal with a higher work function which also interacts with $a-\mathrm{Si}: \mathrm{H}$ at low temperatures may prove to be more appropriate for the $\operatorname{MIS}\left(\mathrm{p}^{+}\right)$, for example, nickel $^{33}$ or gold. ${ }^{34}$

\section{B. Significance to solar cells}

The trends presented in Sec. IV A are revealing in themselves, showing the diverging behavior of contact passivation and conductivity with the dielectric layer thickness. This opposing behavior highlights the difficulty in determining the best $\rho_{\mathrm{c}}-J_{0 \mathrm{c}}$ combination. The simplest application of the contact structures described in this paper would be as a full area contact on the rear side of solar cells. But, as it is well known, it is also possible to form the contact only in part of the rear surface, either as dots or lines. In a device design with partial rear contacts, the remaining surfaces can by passivated by an appropriate dielectric film. This design implies that carrier flow towards the contacts is geometrically constricted, ${ }^{36,37}$ thus adding an element of resistance, for both majority and minority carriers, to the specific contact characteristics $\rho_{\mathrm{c}}$ and $J_{0 \mathrm{c}}$. Therefore, to properly evaluate a given contact system, it is necessary to consider the geometric configuration in which the contact is to be applied. The latter is globally represented by the fraction of the rear surface occupied by the contact $m_{\mathrm{f}}$.

To compare contact structures, we have modelled an idealized solar cell structure with partial rear contacts using the freeware solar cell simulation program Quokka2. ${ }^{38}$ In these simulations, losses due to front surface recombination, resistance, and shading have been reduced to a minimum or removed completely in order to emphasize the influence of the rear contact. The rear contact is simulated with a variable $\rho_{\mathrm{c}}$ and $J_{0 \mathrm{c}}$; for every $\rho_{\mathrm{c}}-J_{0 \mathrm{c}}$ combination an optimum contact fraction $m_{\mathrm{f}}$ is calculated (dashed lines) - and from this configuration an idealized efficiency is obtained (contours). These results are presented in Figures 9(a) and 9(b) for the contacts on $\mathrm{n}^{+}$and $\mathrm{p}^{+}$diffusions, respectively. Assumptions used in the simulations are detailed in Table I. Both simulations show almost identical results, this is attributable to the very similar resistivity and recombination characteristics of the $\mathrm{n}^{+}$and $\mathrm{p}^{+}$diffusions used in this study.

TABLE I. Parameters, assumptions, and structure used in the idealized cell simulations.

\begin{tabular}{|c|c|c|c|}
\hline Symbol & Parameter & Assumption/value & Simulation structure \\
\hline$J_{\text {ofront }}$ & Front recombination factor & $1 \mathrm{fA} / \mathrm{cm}^{2}$ & Idealized front-side: negligible or \\
\hline$\tau_{\text {bulk }}$ & Bulk lifetime & Richter et al. intrinsic lifetime ${ }^{25}$ & resistive and recombination los \\
\hline$J_{\mathrm{g}}$ & Generation current density & $\sim 42 \mathrm{~mA} / \mathrm{cm}^{2}$ & \\
\hline$W$ & Wafer thickness & $160 \mu \mathrm{m}$ & \\
\hline \multirow[t]{2}{*}{$\rho_{\text {bulk }}$} & \multirow[t]{2}{*}{ Bulk type, resistivity } & $1 \Omega$ cm n-type (Fig. 9(a)) & \\
\hline & & $1 \Omega \mathrm{cm}$ p-type (Fig. 9 (b)) & $\mathrm{p}^{+}$layer $\left(\mathrm{n}^{+}\right.$layer $)$ \\
\hline$J_{\text {Orear }}$ & $\begin{array}{l}\text { Rear recombination factor } \\
\text { (in non-contacted area) }\end{array}$ & $\begin{array}{l}J_{\text {Oideal }}\left(\mathrm{p}^{+}\right)=23.4 \mathrm{fA} / \mathrm{cm}^{2}(\text { Fig. } 9(\mathrm{~b})) \\
J_{\text {Oideal }}\left(\mathrm{n}^{+}\right)=24.8 \mathrm{fA} / \mathrm{cm}^{2}(\text { Fig. } 9(\mathrm{a}))\end{array}$ & $\begin{array}{r}\text { n-type ( } p \text {-type }) \\
\mathrm{n}^{+} \text {layer }\left(\mathrm{p}^{+} \text {layer }\right)\end{array}$ \\
\hline$R_{\text {sh_rear }}$ & Rear diffusion sheet resistance & $100 \Omega / \square$ & \\
\hline \multirow[t]{2}{*}{$m_{\text {frear }}$} & Rear line-contact metal fraction & Finger width $=$ variable & \\
\hline & & Finger pitch $=1000 \mu \mathrm{m}$ & MIS contact: fixed pitch, varible finger width \\
\hline
\end{tabular}


By superimposing the experimentally measured thickness dependent $\rho_{\mathrm{c}}-J_{0 \mathrm{c}}$ trends (presented in Figure 8) on these plots, the insulator thickness which provides the optimum $\rho_{\mathrm{c}}-J_{0 \mathrm{c}}$ configuration is identified as the point which falls within the region of highest efficiency. It can be seen that the trends in efficiency are parallel with the concept of carrierselectivity described in the introduction. That is, reductions in the majority carrier resistivity and minority carrier recombination lead to improvements in carrier-selectivity and hence efficiency.

Similarly, the trends in optimum $m_{\mathrm{f}}$ provide information on the ease of fabrication for a particular contact, with larger $m_{\mathrm{f}}$ values being easier to fabricate. It is worth mentioning that no technological constraints are placed on the width of the rear fingers used in these simulations. Hence, real-world realization of contacts with simulated small optimum $m_{\mathrm{f}}$ values would likely be constrained technologically to larger fractions with lower corresponding efficiencies than those seen in Figure 9.

Included in Figure 9(a) are data points which reflect the contact characteristics of the directly metallized $\mathrm{n}^{+}$contact $\operatorname{MS}\left(\mathrm{n}^{+}\right)$, the basic $\operatorname{MIS}\left(\mathrm{n}^{+}\right)$and the $a$-Si:H capped $\operatorname{MIS}\left(\mathrm{n}^{+}\right)$. This comparison reveals that in this particular instance, the only benefit gained in using the basic $\operatorname{MIS}\left(\mathrm{n}^{+}\right)$over the directly metallized $\mathrm{MS}\left(\mathrm{n}^{+}\right)$contact is the ability to use larger contact fractions at the expense of relatively modest decreases in device efficiency. Integrating the $a$-Si:H capping step, however, is shown to improve the carrier-selectivity (hence efficiency) whilst simultaneously increasing the optimum $m_{\mathrm{f}}$ value. The highest idealized efficiencies of $\sim 26.1 \%$ are obtained on $a$-Si:H capped $\mathrm{MIS}\left(\mathrm{n}^{+}\right)$structures with a $\sim 1.55 \mathrm{~nm} \mathrm{SiO}{ }_{2}$ film which produce a $\rho_{\mathrm{c}}-J_{0 \mathrm{c}}$ combination of $\sim 3 \mathrm{~m} \Omega \mathrm{cm}^{2}$ and $\sim 40 \mathrm{fA} / \mathrm{cm}^{2}$. These values are simulated with an optimum $m_{\mathrm{f}}$ value between $30 \%$ and $50 \%$ - a fraction easily achievable using today's industrial processes.

An alike evaluation of the $\mathrm{p}^{+}$contacts presented in Figure 9(b) reveals a significant loss in carrier-selectivity as a result of transitioning from the directly metallized $\mathrm{MS}\left(\mathrm{p}^{+}\right)$ to the basic $\operatorname{MIS}\left(\mathrm{p}^{+}\right)$. This is due primarily to a larger $\rho_{\mathrm{c}}$. The $a$-Si:H capped MIS( $\left.\mathrm{p}^{+}\right)$also shows small losses in efficiency over the directly metalized case when both are applied in their optimum $m_{\mathrm{f}}$, with corresponding optimized efficiencies of $\sim 25.9 \%$ and $\sim 26.0 \%$, respectively. It can be summarized that the only benefits associated with using either MIS $\left(\mathrm{p}^{+}\right)$contacts is that the lower recombination factors allow the contact to be applied in a larger fraction. The MIS results on $\mathrm{p}^{+}$surfaces might be improved by choosing an alternative to $\mathrm{Al}_{2} \mathrm{O}_{3}$ with a lower figure of merit $f$ (Eq. (1)) and a metal with a larger work function.

\section{CONCLUSION}

A fabrication procedure for carrier-selective MIS contacts that utilizes an $a$-Si:H capped dielectric tunneling layer has been presented. Lightly diffused $(\sim 100 \Omega / \square) \operatorname{MIS}\left(\mathrm{p}^{+}\right)$ and $\mathrm{MIS}\left(\mathrm{n}^{+}\right)$structures, employing $\mathrm{Al}_{2} \mathrm{O}_{3}$ and $\mathrm{SiO}_{2}$ dielectric layers, respectively, have been shown to greatly reduce recombination, while still permitting majority carrier transport. STEM and EDX analysis reveal that the alloying between the $a$-Si:H capping layer and the $\mathrm{Al}$ over-layer is a crucial mechanism in the successful formation of the contact structure.

Based on solar cell device simulations, $\mathrm{SiO}_{2}$ thicknesses in the range of $1.5-1.65 \mathrm{~nm}$ are found to be optimum for the MIS $\left(\mathrm{n}^{+}\right)$contacts, resulting in $\rho_{\mathrm{c}}-J_{0 \mathrm{c}}$ combinations of $\sim 3 \mathrm{~m}$ $\Omega \mathrm{cm}^{2}$ and $\sim 40 \mathrm{fA} / \mathrm{cm}^{2}$. These simulations suggest that the $\operatorname{MIS}\left(\mathrm{n}^{+}\right)$contacts can be applied in large area fractions, and hence also offer advantages over established high efficiency silicon solar cell approaches in terms of process simplicity. The thermal stability of the $\operatorname{MIS}\left(\mathrm{n}^{+}\right)$contacts at $350^{\circ} \mathrm{C}$ has also been demonstrated, suggesting that they can be integrated with a standard PECVD $a-\mathrm{SiN}_{\mathrm{x}}: \mathrm{H}$ process.

The $\operatorname{MIS}\left(\mathrm{p}^{+}\right)$contacts revealed poorer characteristics than $\operatorname{MIS}\left(\mathrm{n}^{+}\right)$contacts both in terms of thermal stability and $\rho_{\mathrm{c}}-J_{0 \mathrm{c}}$ combinations, but still offer advantages over conventional approaches based on selective dopant diffusions.

\section{ACKNOWLEDGMENTS}

The authors wish to thank Dr. Andreas Fell for his assistance with the Quokka2 simulations. The authors from the ANU acknowledge financial support by The Australian Solar Institute/Australian Renewable Energy Agency as well as access to equipment at the Australian National Fabrication Facility. The authors from EPFL thank the Axpo Naturstrom Fonds, the European Commission (FP7 project Hercules), the EuroTech Universities Alliance and the Swiss Commission for Technology and Innovation for their financial support. The authors thank Daniele Laub (EPFL) for the STEM sample preparation.

${ }^{1}$ J. Bullock, D. Yan, and A. Cuevas, "Passivation of aluminium $\mathrm{n}^{+}$silicon contacts for solar cells by ultrathin $\mathrm{Al}_{2} \mathrm{O}_{3}$ and $\mathrm{SiO}_{2}$ dielectric layers," Phys. Status Solidi RRL 7, 946 (2013).

${ }^{2}$ S. M. Sze and K. K. Ng, Physics of Semiconductor Devices, 3rd ed. (Wiley, 2007).

${ }^{3}$ Y.-C. Yeo, T.-J. King, and C. Hu, "Direct tunneling leakage current and scalability of alternative gate dielectrics," Appl. Phys. Lett. 81, 2091 (2002).

${ }^{4}$ M. A. Green, A. W. Blakers, M. R. Willison, T. Szpitalak, E. M. Keller, E. Gauja, and P. J. Hart, "The MINP solar cell—a new high voltage, high efficiency silicon solar cell," in Proceedings of the 15th IEEE Photovoltaic Specialist Conference, Kissimmee, USA (1981), p. 1405.

${ }^{5}$ J. Schmidt, A. Merkle, R. Brendel, B. Hoex, M. C. M. van de Sanden, and W. M. M. Kessels, "Surface passivation of high-efficiency silicon solar cells by atomic-layer-deposited $\mathrm{Al}_{2} \mathrm{O}_{3}$," Prog. Photovoltaics 16(6), 461 (2008).

${ }^{6}$ K. Jäger-Hezel, W. Schmidt, W. Helt, and K. D. Rasch, "Improved large area MIS-contacted silicon solar cells," in Proc. 13th EU PVSEC (1995), p. 1515.

${ }^{7}$ D. Zielke, J. H. Petermann, F. Werner, B. Veith, R. Brendel, and J. Schmidt, "Contact passivation in silicon solar cells using atomic-layer-deposited aluminum oxide layers," Phys. Status Solidi RRL 5, 298 (2011).

${ }^{8}$ X. Loozen, J. Larsen, F. Dross, M. Aleman, T. Bearda, B. O'Sullivan, I. Gordon, and J. Poortmans, "Passivation of a metal contact with a tunneling layer," in Proc. 3rd Workshop Metallization Crystalline Silicon Sol. Cells (2011), pp. 25-26.

${ }^{9}$ J. Deckers, E. Cornagliotti, M. Debucquoya, I. Gordona, R. Mertensa, and J. Poortmans, "Aluminum oxide-aluminum stacks for contact passivation in silicon solar cells," in Proc. 4th International Conference on Silicon Photovoltaics (2014).

${ }^{10}$ A. Richter, J. Benick, M. Hermle, and S. W. Glunz, "Excellent silicon surface passivation with $5 \AA$ thin $\mathrm{ALD} \mathrm{Al}_{2} \mathrm{O}_{3}$ layers: Influence of different thermal post-deposition treatments," Phys. Status Solidi RRL 5, 202 (2011). 
${ }^{11}$ W. Liang, K. Weber, and A. Thomson, "Effective $\mathrm{SiN}_{\mathrm{x}}: \mathrm{H}$ capping layers on $1 \mathrm{~nm} \mathrm{Al}_{2} \mathrm{O}_{3}$ for $\mathrm{p}^{+}$surface passivation," IEEE Journal of Photovoltiacs 4, 1405 (2014).

${ }^{12}$ A. A. Langford, M. L. Fleet, B. P. Nelson, W. A. Lanford, and N. Maley, "Infrared absorption strength and hydrogen content of hydrogenated amorphous silicon," Phys. Rev. B 45, 13367 (1992).

${ }^{13}$ J. Bullock, D. Yan, Y. Wan, A. Cuevas, B. Demaurex, A. Hessler-Wyser, and S. De Wolf, "Amorphous silicon passivated contacts for diffused junction silicon solar cell," J. Appl. Phys. 115, 163703 (2014).

${ }^{14}$ J. L. Murray and A. J. McAlister, "The Al-Si (Aluminum-Silicon) system," Bull. Alloy Phase Diagrams 5, 74 (1984).

${ }^{15}$ M. S. Haque, H. A. Naseem, and W. D. Brown, "Interaction of aluminum with hydrogenated amorphous silicon at low temperatures," J. Appl. Phys. 75, 3928 (1994)

${ }^{16} \mathrm{O}$. Nast and S. R. Wenham, "Elucidation of the layer exchange mechanism in the formation of polycrystalline silicon by aluminum-induced crystallization," J. Appl. Phys. 88, 124 (2000).

${ }^{17}$ B.-Y. Tsaur, G. W. Turner, and J. C. C. Fan, "Efficient Si Solar cells by low-temperature solid-phase epitaxy," Appl. Phys. Lett. 39, 749 (1981).

${ }^{18}$ H. Plagwitz, M. Nerdling, N. Ott, H. P. Strunk, and R. Brendal, "Low-temperature formation of local $\mathrm{Al}$ contacts to $a$-Si:H passivated $\mathrm{Si}$ wafers," Prog. Photovoltaics: Res. Appl. 12, 47 (2004).

${ }^{19}$ B. J. Hallam, P. G. Hamer, S. R. Wenham, M. D. Abbot, A. Sugianto, A. M. Wenham, C. E. Chan, G. Q. Xu, J. Kariem, J. Degoulange, and R. Einhaus, "Advance bulk defect passivation for silicon solar cells," IEEE J. Photovoltaics 4, 88 (2014).

${ }^{20}$ B. J. Hallam, A. Sugianto, L. Mai, G. Q. Xu, C. E. Chan, M. D. Abbot, S. R. Wenham, A. Uruena, E. Cornagliotti, and M. Aleman, "Hydrogen passivation of laser-induced defects for laser-doped silicon solar cells," IEEE J. Photovoltaics 4, 1413 (2014).

${ }^{21}$ A. Bierhals, A. G. Aberle, and R. Hezel, "Improved understanding of thermally activated structural changes in $\mathrm{Al} / \mathrm{SiO}_{\mathrm{x}} / \mathrm{p}$-Si tunnel diodes by means of infrared spectroscopy," J. Appl. Phys. 83, 1371 (1998).

${ }^{22}$ R. L. Puurunen, W. Vandervorst, W. F. A. Besling, O. Richard, H. Bender, T. Conard, C. Zhao, A. Delabie, M. Caymax, S. De Gendt, M. Heyns, M. M. Viitanen, M. de Ridder, H. H. Brongersma, Y. Tamminga, T. Dao, T. de Win, M. Verheijen, M. Kaiser, and M. Tuominen, "Island growth in the atomic layer deposition of zirconium oxide and aluminum oxide on hydrogen-terminated silicon: Growth mode modeling and transmission electron microscopy," J. Appl. Phys. 96, 4878 (2004).

${ }^{23}$ D. E. Kane and R. M. Swanson, "Measurement of the emitter saturation current by a contactless photoconductivity decay method," in Proceedings of the 18th IEEE Photovoltaic Specialist Conference, Las Vegas, USA (1985), pp. 578-583.
${ }^{24}$ B. Hoex, J. Schmidt, R. Bock, P. P. Altermatt, M. C. M. van de Sanden, and W. M. M. Kessels, "Excellent passivation of highly doped p-type Si surfaces by the negative-charge-dielectric $\mathrm{Al}_{2} \mathrm{O}_{3}$," Appl. Phys. Lett. 91, 112107 (2007).

${ }^{25}$ A. Richter, S. W. Glunz, F. Werner, J. Schmidt, and A. Cuevas, "Improved quantitative description of Auger recombination in crystalline silicon,” Phys. Rev. B 86, 165202 (2012).

${ }^{26}$ D. B. M. Klaassen, "A unified mobility model for device simulation-I. Model equations and concentration dependence," Solid-State Electron. 35, 953 (1992).

${ }^{27} \mathrm{D}$. Yan and A. Cuevas, "Empirical determination of the energy band gap narrowing in highly doped $\mathrm{n}^{+}$silicon," J. Appl. Phys. 114, 044508 (2013).

${ }^{28} \mathrm{D}$. Yan and A. Cuevas, "Empirical determination of the energy band gap narrowing in $\mathrm{p}^{+}$silicon heavily doped with boron," J. Appl. Phys. (submitted).

${ }^{29}$ A. Cuevas, R. Merchan, and J. C. Ramos, "On the systematic analytical solutions for minority-carrier transport in non-uniform doped semiconductors: Application to solar cells," IEEE Trans. Electron Devices 40, 1181 (1993).

${ }^{30}$ D. K. Schroder, Semiconductor Material and Device Characterization (Wiley, Hoboken, 2006), p. 146.

${ }^{31}$ J. Robertson, "Band offsets, Schottky barrier heights, and their effects on electronic devices," J. Vac. Sci. Technol., A 31, 050821 (2013).

${ }^{32}$ L. E. Black and K. R. McIntosh, "Modeling recombination at the $\mathrm{Si}_{-} \mathrm{Al}_{2} \mathrm{O}_{3}$ interface," IEEE J. Photovoltaics 3, 936 (2013).

${ }^{33}$ Z. Jin, G. A. Bhat, M. Yeung, H. S. Kwok, and M. Wong, "Nickel induced crystallization of amorphous silicon thin films," J. Appl. Phys. 84, 194 (1998).

${ }^{34}$ L. Hultman, A. Robertsson, H. T. G. Hentzell, I. Engstrom, and P. A. Psaras, "Crystallization of amorphous silicon during thin film gold reaction," J. Appl. Phys. 62, 3647 (1987).

${ }^{35}$ J. Bullock, A. Cuevas, D. Yan, B. Demaurex, A. Hessler-Wyser, and S. De Wolf, "Passivated contacts to $\mathrm{n}^{+}$and $\mathrm{p}^{+}$silicon based on amorphous silicon and thin dielectrics," in Proceedings of the 40th IEEE Photovoltaic Specialist Conference, Denver, USA (2014).

${ }^{36}$ A. Cuevas, "Physical model of back line-contact front-junction solar cells," J. Appl. Phys. 113, 164502 (2013).

${ }^{37}$ A. Cuevas, "Geometrical analysis of solar cells with partial rear contacts," IEEE J. Photovoltaics 2, 485-493 (2012).

${ }^{38} \mathrm{~A}$. Fell, "A free and fast 3D/2D solar cell simulator featuring conductive boundary and quasi-neutrality approximations," IEEE Trans. Electron Devices 60, 733 (2013). 